\title{
Identificação e Caracterização de um Potyvírus Isolado de Zinnia elegans*
}

\author{
Ana C. Maritan ${ }^{1 * *}$, José O. Gaspar ${ }^{1 * * *}$ \& Luis E. A. Camargo ${ }^{2}$ \\ ${ }^{1}$ Departamento de Zoologia e Botânica, IBILCE/UNESP, CEP 15054-000 São José do Rio Preto, SP, e-mail: \\ gaspar@dzb.ibilce.unesp.br; ${ }^{2}$ Lab. de Biologia Molecular, ESALQ/USP, Cx. Postal 9, CEP 13418-900, Piracicaba, SP
}

(Aceito para publicação em 06/11/2003)

Autor para correspondência: José Osmar Gaspar

MARITAN, A.C., GASPAR, J.O. \& CAMARGO, L.E.A. Identificação e caracterização de um potyvírus isolado de Zinnia elegans. Fitopatologia Brasileira 29:028-033. 2004.

\section{RESUMO}

O presente trabalho teve como objetivo a identificação e caracterização de um potyvírus isolado de Zinnia elegans, na Região Noroeste do Estado de São Paulo. O potyvírus foi transmitido por inoculação mecânica e apresentou uma gama restrita de hospedeiras sendo que as espécies mais afetadas pertencem à família Asteraceae. Em SDS-PAGE, a massa molecular da proteína capsidial (CP) foi estimada em $33 \mathrm{kDa}$ e, em "Western-blot", reagiu com anti-soro para o Bidens mosaic virus (BiMV). Um fragmento de aproximadamente $820 \mathrm{pb}$ foi amplificado por RT/PCR, clonado e seqüenciado. $\mathrm{O}$ fragmento, que inclui o gene da proteína capsidial, mostrou similaridade de aminoácidos do "core" da CP variando de $55 \%$ (Tobacco vein mottling virus, TVMV) a 95\% (Sunflower chlorotic mottle virus, SuCMoV) e da CP completa de 55\% (TVMV) a $91 \%(\mathrm{SuCMoV})$. Na região N-terminal, o potyvírus de Zinnia tem uma deleção de quatro aminoácidos (posições 9 a 12 após o sítio de clivagem entre a proteína $\mathrm{NIb}$ e a $\mathrm{CP}$ ) quando comparada com a seqüência do SuCMoV. A análise filogenética agrupou o potyvírus de Zinnia e o SuCMoV em um mesmo ramo em $100 \%$ das réplicas, mostrando uma relação de parentesco muito próxima entre esses dois vírus. Os resultados obtidos no presente trabalho demonstraram que o potyvírus de Zinnia e o SuCMoV são estirpes do mesmo vírus. Sugere-se o nome Sunflower chlorotic mottle virus, isolado Zinnia (SuCMoV-Zi), ao potyvírus encontrado em Z. elegans no Brasil.

Palavras-chave adicionais: Sunflower chlorotic mottle virus, girassol, Asteraceae, Bidens, filogenia.

\section{ABSTRACT}

Identification and characterization of a potyvirus isolated from Zinnia elegans

The present work describes the identification and characterization of a potyvirus isolated from Zinnia elegans in the northwest region of the State of São Paulo, Brazil. The Zinnia potyvirus was transmitted by mechanical inoculation. Its host range was restricted mainly to members of the Asteraceae family. By SDS-PAGE, the molecular mass of the coat protein (CP) was estimated to be $33 \mathrm{kDa}$ and, in Western-blot, it reacted with antiserum to Bidens mosaic virus (BiMV). A fragment of about $820 \mathrm{bp}$ was amplified by RT/PCR, cloned and sequenced. The fragment, which included the $\mathrm{CP}$ gene, displayed amino acids similarity in the CP core ranging from $55 \%$ (Tobacco vein mottling

\section{INTRODUÇÃO}

As estatísticas sobre o setor de flores e plantas ornamentais no Brasil são muitas vezes desorganizadas e contraditórias. Apesar da inexistência de levantamento sistemático sobre o assunto, estima-se que o comércio de flores movimente, no varejo, entre R\$1,36 e 1,53 bilhões anualmente. O Estado de

\footnotetext{
*Parte da Dissertação de Mestrado da primeira autora. Universidade Estadual Paulista (2002). Apoio financeiro da FAPESP e CAPES. Sequência depositada no GenBank com o número de acesso AY344048. **Bolsista da CAPES

$* * *$ Bolsista do $\mathrm{CNPq}$
}

virus, TVMV) to $95 \%$ (Sunflower chlorotic mottle virus, $\mathrm{SuCMoV}$ ). For the whole $\mathrm{CP}$, it ranged from 55\% (TVMV) to $91 \%(\mathrm{SuCMoV})$. In the N-terminal region the Zinnia potyvirus has a deletion of four amino acids (positions 9 to 12 downstream of the cleavage site between the protein $\mathrm{NIb}$ and the $\mathrm{CP}$ ) when compared with the SuCMoV sequence. Filogenetic analysis grouped the Zinnia potyvirus and SuCMoV in the same branch in $100 \%$ of the replicates, showing a very close relationship between these two viruses. The results obtained in the present work demonstrate that the Zinnia potyvirus and SuCMoV are strains of the same virus. The name Sunflower chlorotic mottle virus, Zinnia isolate (SuCMoV-Zi), is suggested for the potyvirus found in Z. elegans in Brazil.
São Paulo destaca-se entre os estados produtores de flores no panorama nacional, participando com $71,3 \%$ da área cultivada e 74,5\% do valor da produção no País (Aki, 2001).

Zinnia elegans Jacq, popularmente conhecida como capitão, moça-e-velha, canela-de-velho ou zínia, é uma angiosperma da família Asteraceae, originária do México. É uma planta herbácea anual de caule ereto, folhagem áspera, flores pequenas reunidas em capítulos grandes de várias cores e formas (Gemtchújnicov, 1976). É uma ornamental cultivada para a produção de flor de corte devido a sua longa durabilidade, sendo adequada também para a utilização em bordaduras e maciços a pleno sol, tanto para regiões de 
temperatura amena como para áreas tropicais. Multiplica-se por sementes que podem ser semeadas durante o ano todo, principalmente na primavera e verão (Lorenzi \& Souza, 1999).

Em várias partes do mundo, Z. elegans foi descrita como hospedeira natural ou experimental de espécies virais pertencentes a diversos gêneros, citando-se Alfamovirus, Nepovirus, Potexvirus, Carlavirus, Potyvirus, Ilarvirus, Luteovirus, Tospovirus, Tobamovirus, Closterovirus, Tombusvirus e Nucleorhabdovirus (Brunt et al., 1996). Em relação ao gênero Potyvirus, Z. elegans foi infetada, entre outras, pelas espécies Bean yellow mosaic virus (BYMV), Bidens mosaic virus (BiMV), Bidens mottle virus (BiMoV), Lettuce mosaic virus (LMV), Papaya ringspot virus "W" (PRSV), Pea seed-borne mosaic virus (PSbMV), Pepper veinal mottle virus (PVMV), Plum pox virus (PPV), Tobacco etch virus (TEV) e Turnip mosaic virus (TuMV) (Brunt et al., 1996).

No Brasil, Z. elegans foi descrita como naturalmente infetada pelo BiMV (Kitajima \& Lima, 1991), um potyvírus que, nos anos 60, foi responsável por grandes prejuízos para a cultura do girassol (Helianthus annuus L.) (Costa \& Kitajima, 1966). Recentemente, foram encontradas, em um canteiro experimental da UNESP de São José do Rio Preto, plantas de $Z$. elegans exibindo mosqueado, mosaico, deformação foliar (Figura 1A) e flores com alterações no padrão de coloração (Figura 1B). Observações ao microscópio eletrônico de extratos de folhas dessas plantas evidenciaram a presença de partículas com aproximadamente $750 \mathrm{~nm}$ de comprimento e com morfologia típica de espécies do gênero Potyvirus.

O objetivo principal do presente trabalho foi identificar e caracterizar o potyvírus encontrado em Z. elegans na Região Noroeste do Estado de São Paulo.

\section{MATERIALEMÉTODOS}

\section{Isolado do vírus}

O potyvírus utilizado neste estudo foi obtido de planta de Z. elegans, com sintoma de mosaico, encontrada no Campus da Universidade Estadual Paulista (UNESP) de São José do Rio Preto. Uma folha de Z. elegans foi macerada em tampão fosfato de potássio $0,02 \mathrm{M}, \mathrm{pH} \mathrm{7,4}$ (contendo sulfito de sódio $0,02 \mathrm{M}$ ) e manualmente inoculada em folhas de Chenopodium quinoa Willd, utilizando-se Celite (Sigma) como abrasivo. Uma única lesão local clorótica foi isolada, macerada no mesmo tampão e inoculada em Nicotiana occidentalis Wheeler. Esta planta foi, então, utilizada como fonte de inóculo para os demais experimentos.

\section{Determinação de gama de hospedeiras}

$\mathrm{O}$ vírus foi mecanicamente inoculado nas seguintes plantas indicadoras: Asteraceae [Z. elegans, H. annuus, Bidens pilosa L., Emilia sonchifolia (L.) DC., Lactuca sativa L., Cichorium intybus L.], Chenopodiaceae ( $C$. quinoa), Cruciferae (Brassica oleracea L. var. acephala), Cucurbitaceae (Cucumis sativus L.), Solanaceae (Lycopersicon esculentum Mill., Petunia hybrida Vilm, N. tabacum L. 'TNN', N. rustica L., $N$. benthamiana Domin., N. glutinosa L., N. occidentalis),
Leguminosaea (Phaseolus vulgaris L., Arachis hypogea L.), Amarantaceae (Gomphrena globosa L.) e Malvaceae (Gossypium hirsutum L).

Purificação do vírus, eletroforese (SDS-PAGE) e reação sorológica

Preparações purificadas do potyvírus de Z. elegans foram obtidas conforme descrito por Della Vecchia (2001), a partir de $100 \mathrm{~g}$ de folhas de $N$. occidentalis, 15 dias após a inoculação. A proteína capsidial (CP) e extratos de folhas sadias e infetadas foram analisadas por SDS-PAGE e "Western-blot" com anti-soro para o BiMV (doação do Dr. E. W. Kitajima).

\section{Amplificação por RT/PCR, clonagem e seqüenciamento}

O RNA viral foi extraído do vírus purificado usando-se o kit "RNeasy Plant Mini" de acordo com instruções do fabricante (Qiagen). O cDNA foi sintetizado usando-se a enzima "Superscript II Reverse Transcriptase" (Gibco-BRL) e o oligonucleotídeo anti-senso 5'-GCTGGTTCGTAACATGTGA3'. O cDNA foi amplificado por PCR utilizando-se "Taq polimerase" (Gibco-BRL), o oligonucleotídeo anti-senso descrito acima e o oligonucleotídeo senso 5'-GGAACGTATGA AGTGCACCA-3'. Esses oligonucleotídeos foram desenhados a partir da seqüência do Sunflower chlorotic mottle virus (SuCMMoV) (GenBank AF255677). A reação de PCR consistiu

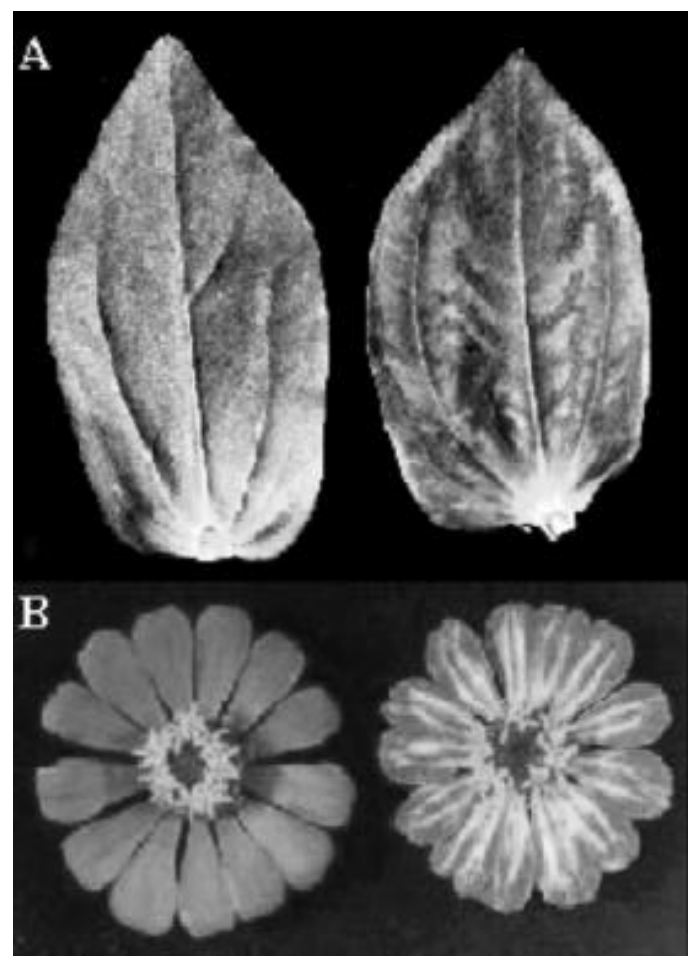

FIG. 1 - (A) Folha de Zinnia elegans mostrando sintoma de mosaico (direita) e folha de planta sadia (esquerda). (B) Descoloração apresentada por uma flor de Z. elegans infetada (direita) comparada com uma flor de planta sadia (esquerda). 


\section{A.C. Maritan et al.}

de desnaturação inicial por 10 min e 30 ciclos de 1 min de desnaturação a $94{ }^{\circ} \mathrm{C}, 1$ min de anelamento dos oligonucleotídeos a $47^{\circ} \mathrm{C}$ e 2 min de extensão a $72^{\circ} \mathrm{C}$, em um Termociclador MJ Research. O produto de amplificação foi clonado utilizandose o kit "SureClone Ligation", de acordo com instruções do fabricante (Amersham Pharmacia). O seqüenciamento de três clones, em ambas as direções, foi feito utilizando-se os oligos universais M13 (senso e anti-senso) e o kit "DNA sequencing Big-Dye Terminator Cycle Sequencing Ready Reaction (Perkin Elmer) em um sequenciador ABI Prism 377 (Applied Biosystems, Inc).

\section{Análise do produto seqüenciado}

A análise comparativa das seqüências foi feita através do algoritmo BLAST (http://www.ncbi.nlm.nih.gov) e o alinhamento das seqüências consenso pelo programa Multalin (http://prodes.toulouse.inra.fr/multalin/multalin.html). A seqüência de aminoácidos deduzidos da proteína capsidial foi determinada pelo programa Translate (http://www.expasy.org/ tolls/dna.html). As relações filogenéticas foram determinadas pelo método "neighbor-joining" com auxílio do programa PAUP v.4.0b10 (Swofford, 1997) com análise de "bootstrap" de 500 réplicas. A construção gráfica da árvore foi feita pelo programa Tree View 1.6.1.

\section{RESULTADOS}

\section{Hospedeiras e sintomatologia}

O potyvírus de Zinnia induziu lesões locais clóroticas nas folhas inoculadas de C. quinoa e N. tabacum TNN. As plantas infetadas sistemicamente foram: Z. elegans (mosaico), $H$. annuus (mosaico, necrose e eventual morte da planta), $E$. sonchifolia (mosaico) e N. occidentalis (mosaico, enrugamento foliar e retardo do crescimento). As plantas não infetadas foram: A. hypogea, B. pilosa, L. sativa, C. intybus, B. oleracea var. acephala, C. sativus, L. esculentum, $P$. hybrida, N. rustica, $N$. benthamiana, N. glutinosa, P. vulgaris, G. globosa e G. hirsutum.

\section{Massa molecular da proteína capsidial e relação sorológica com o BiMV}

Quando uma alíquota do vírus purificado foi aplicada em gel desnaturante de poliacrilamida (SDS-PAGE) (Figura 2A, coluna 1) ficou evidenciada a presença da proteína capsidial do potyvírus de Zinnia com massa molecular estimada de 33 $\mathrm{kDa}$, conforme determinação comparativa com proteínas de massas moleculares conhecidas (coluna M).

Por "Western-blot" seguido de reação com anti-soro específico para o BiMV, detectou-se reação com a proteína de $33 \mathrm{kDa}$, tanto na amostra do vírus purificado como na amostra de proteínas totais obtidas de planta infetada pelo potyvírus de Zinnia (Figura 2B). Não houve reação com as proteínas extraídas da planta sadia.

\section{Amplificação por RT/PCR, clonagem e seqüenciamento}

Um fragmento de tamanho esperado de aproxima- damente $820 \mathrm{pb}$ foi amplificado por RT/PCR (Figura 3). Após clonagem em vetor pUC18, bactérias Escherichia coli foram transformadas e cinco colônias contendo plasmídeos recombinantes foram selecionadas. Os plasmídeos extraídos foram duplamente digeridos com as enzimas EcoRI e HindIII, liberando um fragmento de aproximadamente $820 \mathrm{pb}$. A identidade viral do fragmento foi positivamente demonstrada por "Southern-blot" e hibridização com sonda específica para o potyvírus de Zinnia (Dados não apresentados).

$\mathrm{O}$ seqüenciamento do fragmento viral mostrou a existência de $822 \mathrm{pb}$, correspondendo aos $27 \mathrm{nt}$ finais do gene da proteína NIb (9aa) e aos 795 nt da região codificadora da proteína capsidial (264aa), incluindo-se o códon de terminação UGA. A seqüência de nucleotídeos e os aminoácidos deduzidos do gene da proteína capsidial são mostrados na Figura 4. A

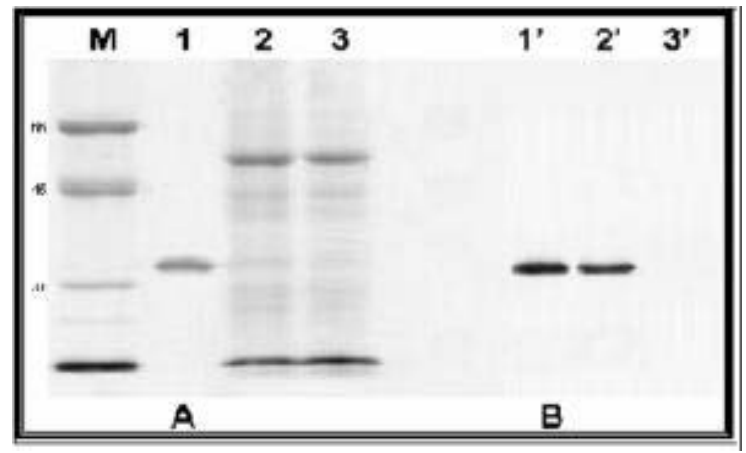

FIG. 2 - A: Perfil eletroforético do potyvírus de Zinnia purificado (1), proteínas totais de planta infetada (2) e proteínas totais de planta sadia (3) em gel desnaturante de poliacrilamida (SDS-PAGE). B: "Western-blot" e reação imunológica com anti-soro para o BiMV, de um gel similar ao A. M: Marcador de peso molecular Low Range (BioRad).

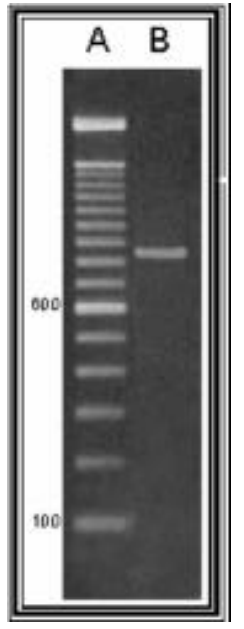

FIG. 3 - Análise do produto de amplificação por PCR em gel nativo de agarose. (A) marcador molecular DNA 100pb (Gibco). (B) fragmento amplificado de aproximadamente $820 \mathrm{pb}$ do potyvirus isolado de Zinnia elegans. 
similaridade entre a seqüência completa da proteína capsidial e também o "core" (região interna conservada da proteína capsidial) do potyvírus de Zinnia e alguns outros potyvírus está demonstrada na Tabela 1.

Os resultados da análise filogenética das seqüências dos potyvírus, usando-se o método de "neighbor-joining", estão mostrados na Figura 5. A árvore obtida mostra o potyvírus de Zinnia e o SuCMoV juntos em um mesmo ramo em 100\% das 500 réplicas.

\section{DISCUSSÃO}

Os potyvírus possuem uma gama variável de hospedeiras, sendo que alguns infetam poucas espécies e outros chegam a infetar espécies de até 30 famílias diferentes. A maioria afeta plantas cultivadas causando grandes prejuízos econômicos. O potyvírus de Zinnia foi facilmente transmitido por inoculação mecânica e apresentou uma gama restrita de hospedeiras. Induziu, na maioria dos casos, mosaico ou mosqueado, sendo que as espécies mais afetadas pertencem à família Asteraceae. No girassol, onde a infecção mostrou sua forma mais severa, as plantas muito jovens chegaram à morte, indicando que o potyvírus de Zinnia pode vir a ser uma ameaça para esta cultura.

Algumas das hospedeiras (H. annuus, $C$. amaranticolor, C. quinoa, Z. elegans) bem como os sintomas induzidos pelo potyvírus de Zinnia nessas plantas, são similares àqueles apresentados pelo BiMV (Kuhnet al., 1980), BiMoV (Christie et al., 1968) e SuCMoV (Dujovny et al., 1998). Não obstante, o potyvírus de Zinnia e o SuCMoV não infetaram alface (L. sativa), ao contrário do BiMV e BiMoV. Além disso,

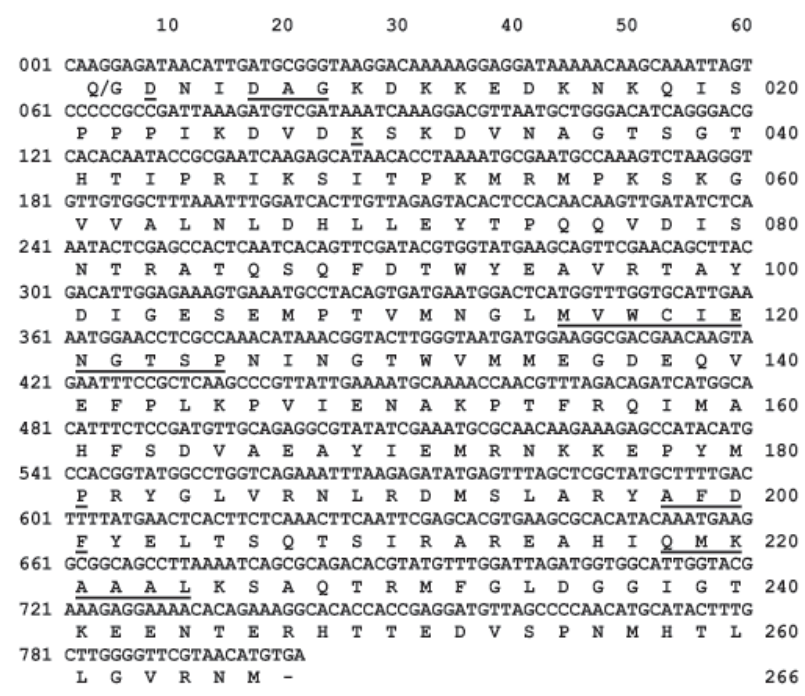

FIG. 4 - Seqüência de nucleotídeos (superior) e aminoácidos deduzidos (inferior) do gene da proteína capsidial do potyvírus de Zinnia. Q/G: Sítio de clivagem entre a NIb e a CP. $\underline{\mathrm{D}}$, início da CP. Seqüências sublinhadas: motivos conservados da $\mathrm{CP}$ dos potyvírus. $\underline{\mathrm{K}}$ (posição 32) e $\underline{P}$ (posição 184): limites do "core" da CP. o potyvírus de Zinnia não infetou o picão (B. pilosa L.), que é hospedeira do BiMV, BiMoV e SuCMoV. Entretanto, essas variações na gama de hospedeiras podem ser causadas por diferenças nas cultivares utilizadas. No geral, o potyvírus de Zinnia se assemelhou mais a $\mathrm{SuCMoV}$ do que ao BiMV e BiMoV.

A massa molecular da proteína capsidial ( $\sim 33 \mathrm{kDa})$ está entre os valores obtidos para a maioria dos potyvírus (de 28 a $47 \mathrm{kDa}$ ) (Allison et al., 1985; Hollings \& Brunt, 1981) e foi similar aos valores encontrados para o SuCMoV (Dujovny et al., 1998) e para o BiMV (Nagata et al., 1995). Os resultados do "Western-blot" indicaram que o potyvírus de Zinnia possui relação sorológica com o BiMV. Levando-se em consideração que BiMV, BiMoV e SuCMoV são sorologicamente relacionados (Nagata et al., 1995; Dujovny et al., 1998), podese inferir que o potyvírus de Zinnia é também relacionado ao BiMoV e SuCMoV. Entretanto, a utilização da sorologia para determinação do grau de parentesco entre espécies de potyvírus não tem sido utilizada com sucesso, devido a ocorrência de reações cruzadas entre os vírus (Shukla et al., 1991; Ward \& Shukla, 1991). Isso tem levado à utilização do critério de similaridade de nucleotídeos para a determinação de parentesco entre os potyvírus (Ward et al., 1992)

TABELA 1 - Porcentagem de identidade entre o potyvírus de Zinnia e outros potyvírus

\begin{tabular}{llcc}
\hline \hline \multirow{2}{*}{ Potyvirus } & N Nacesso no $^{\circ}$ & \multicolumn{2}{c}{ Homologia } \\
\cline { 3 - 4 } & GenBank & "Core" & CP \\
\hline SuCMoV 95 & AF255677 & 95 & 91 \\
PVY-T & D12570 & 85 & 81 \\
PVY-H & M95491 & 86 & 81 \\
PVY-Fr & D00441 & 84 & 80 \\
PVY-Nus & U09508 & 86 & 81 \\
PVY-Eur & X68223 & 85 & 81 \\
PVY-N-Rus & X54636 & 84 & 80 \\
PVY(Chil.) & X68221 & 86 & 81 \\
PVY (0') & X68226 & 86 & 80 \\
PVY (04) & D12539 & 85 & 80 \\
PVY (0, & X14136 & 86 & 80 \\
PVY-NsNr & X68224 & 86 & 82 \\
PepMoV & M11598 & 86 & 81 \\
LMV & Z78228 & 71 & 65 \\
BCMV & L11890 & 63 & 60 \\
TuMV & AJ000690 & 67 & 64 \\
TEV & M15239 & 62 & 62 \\
MDMV & AJ001691 & 63 & 60 \\
SCMV & X98166 & 58 & 62 \\
TVMV & X04083 & 55 & 55 \\
PRSV & NC001785 & 64 & 61 \\
ZYMV & AJ429071 & 64 & 61 \\
WMV-2 & L22907 & 62 & 60 \\
PWV & U67149 & 60 & 57 \\
\hline SWMV, & & 60 &
\end{tabular}

SuCMoV, Sunflower chlorotic mottle virus; PVY, Potato virus $Y$; PepMoV, Pepper mottle virus; LMV, Lettuce mosaic virus; BCMV, Bean common mosaic virus; TuMV, Turnip mosaic virus; TEV, Tobacco etch virus; MDMV, Maize dwarf mosaic virus; SCMV, Sugarcane mosaic virus; TVMV, Tobacco vein mottling virus; PRSV, Papaya ringspot virus; ZYMV, Zucchini yellow mosaic virus; WMV-2, Watermelon mosaic virus 2; PWV, Passionfruit woodiness virus. 


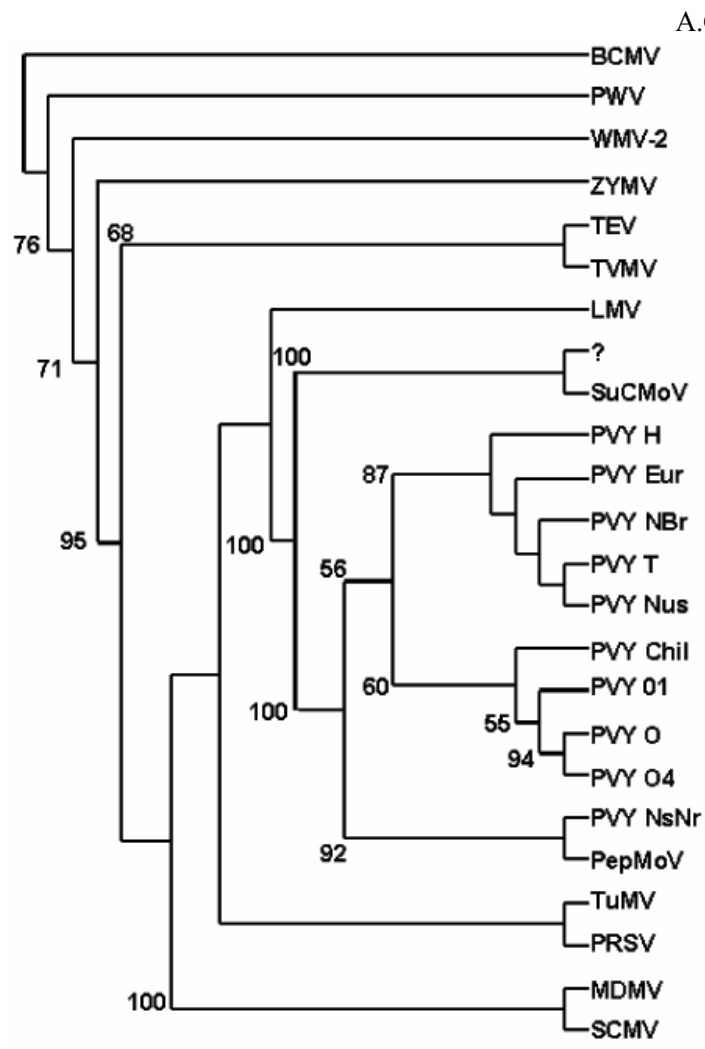

FIG. 5 - Dendograma obtido a partir da análise filogenética por parcimônia com base na seqüência completa de aminoácidos da CP do potyvírus de Zinnia (identificado por sinal de interrogação) e outros potyvírus. As porcentagens de "bootstrap" são indicadas nos ramos da árvore (porcentagens menores que $50 \%$ não são mostradas). $\mathrm{BCMV}$, Bean common mosaic virus; PWV, Passionfruit woodiness virus, WMV-2, Watermelon mosaic virus 2; ZYMV, Zucchini yellow mosaic virus; TEV, Tobacco etch virus; TVMV, Tobacco vein mottling virus; LMV, Lettuce mosaic virus; SuCMoV, Sunflower chlorotic mottle virus; PVY, Potato virus Y; PepMoV, Pepper mottle virus; TuMV, Turnip mosaic virus; PRSV, Papaya ringspot virus; MDMV, Maize dwarf mosaic virus; SCMV, Sugarcane mosaic virus

Devido a grande semelhança das características biológicas entre o potyvírus de Zinnia e o SuCMoV isolado de girassol na Argentina, foi utilizada a seqüência deste vírus (Dujovny et al., 2000) para o desenho de oligonucleotídeos que pudessem amplificar o gene da proteína capsidial do potyvírus de Zinnia. A sequiência do fragmento obtido, quando comparada com seqüências depositadas no GenBank, mostrou similaridade com a de outros potyvírus. Nela foram identificados: (1) o sítio de clivagem entre as proteínas NIb e CP [glutamina (Q)/glicina (G)] que é comum aos vírus pertencentes a família Potyviridae (Van der Vlugt et al., 1993); (2) o motivo DAG (4aa a partir do sítio de clivagem) que está relacionado à transmissão por afídeos e presente na região Nterminal da $\mathrm{CP}$ dos potyvírus assim transmitidos (Atreya et al.,1990; 1991; 1995; Gal-On et al., 1992) e (3) as sequiências altamente conservadas na $\mathrm{CP}$ dos potyvírus: MVWCIENGTSP, AFDF e QMKAAAL localizadas 117, 200 e 220 aminoácidos a partir do sítio de clivagem, respectivamente.

A porcentagem de similaridade das seqüências da $\mathrm{CP}$ completa e do "core" tem sido utilizada para identificar espécies de potyvírus e traçar relações filogenéticas entre eles (Ward et al, 1992; Shukla et al., 1994). Comparações entre seqüências completas da $\mathrm{CP}$ de muitos membros do gênero Potyvirus revelaram que espécies distintas apresentam de 38 a $71 \%$ de similaridade e estirpes de um mesmo vírus têm de 90 a $99 \%$ (Ward et al., 1992), mas há várias exceções a esta regra (McKern et al., 1991; Tracy et al., 1992; Uyeda, 1992). Alguns trabalhos demonstraram que comparações da seqüência do "core" da CP são mais representativas (Shukla et al., 1991; Ward \& Shukla, 1991). Quando a seqüência de aminoácidos do "core" da CP do potyvírus de Zinnia foi alinhada com a seqüência correspondente de outros potyvírus, as porcentagens de similaridade variaram de $55 \%$ a $95 \%$, sendo que o valor máximo foi observado na comparação com o $\mathrm{SuCMoV}$, enquanto que as porcentagens obtidas na comparação da $\mathrm{CP}$ inteira foram de $55 \%$ a $91 \%$.

As maiores variações observadas foram localizadas no $\mathrm{N}$-terminal, uma região altamente variável que se encontra exposta na superfície das partículas dos potyvírus. Nela estão presentes os epitopos vírus-específicos e vários pesquisadores atribuem a variação no tamanho da proteína capsidial dos potyvírus principalmente às diferenças no comprimento desta região, já que o "core" interno (cerca de 220 aminoácidos) permanece conservado dentro do gênero (Sherpherd et al., 1974; Allison et al.,1985; Doughert et al., 1985; Shukla et al., 1986; Shukla et al., 1988). O potyvírus de Zinnia apresentou quatro aminoácidos a menos (posições 9 a 12 após o sítio de clivagem entre a proteína $\mathrm{NIb}$ e a $\mathrm{CP}$ ) quando comparado ao $\mathrm{SuCMoV}$, sendo esta a maior diferença observada entre eles.

A análise filogenética, realizada para as seqüências de aminoácidos correspondentes às proteínas capsidiais de alguns potyvírus, agrupou o potyvírus de Zinnia e o SuCMoV em um mesmo ramo em $100 \%$ das réplicas, confirmando a proximidade entre eles. O agrupamento do potyvírus de Zinnia e o SuCMoV apresentou-se fortemente relacionado com os isolados necróticos e comuns do "Potato virus Y" (PVY). Os demais potyvírus (Tabela 1) foram agrupados mais distantemente. Devido a ausência de dados da seqüência de nucleotídeos do BiMV e BiMoV, não foi possível determinar o grau de parentesco entre estas espécies e o potyvírus de Zinnia.

Os resultados obtidos no presente trabalho demonstraram que o potyvírus de Zinnia e o SuCMoV possuem uma grande similaridade no gene da proteina capsidial que, somadas às semelhanças biológicas em relação a gama de hospedeiras e sintomatologia, permitem considerá-los como estirpes do mesmo vírus. Assim, sugere-se o nome Sunflower chlorotic mottle virus, isolado Zinnia (SuCMoV-Zi), ao potyvírus relatado pela primeira vez em Z. elegans no Brasil.

\section{AGRADECIMENTO}

Ao Dr. Elliot W. Kitajima pela doação do anti-soro para o BiMV. 
Identificação e caracterização de um potyvírus isolado de Zinnia elegans

\section{REFERÊNCIAS BIBLIOGRÁFICAS}

AKI, A. Qual o tamanho do mercado de flores? 2001. Disponível em: $<$ http://www.mercadodasflores.com.br>. Acesso em: 20 de abril de 2002.

ALLISON, R.F., SORENSON, J.C., KELLY, M.E., ARMSTRONG, F.B. \& DOUGHERTY, W.G. Sequence determination of the capsid protein gene and flanking regions of Tobacco etch virus: evidence for synthesis and processing of a polyprotein in potyvirus gene expression. Proceedings of the National Academy of Sciences, U.S.A. 82:3969-3972. 1985.

ATREYA, C.D., RACCAH, B. \& PIRONE, T.P. A point mutation in the coat protein abolishes aphid transmissibility of a potyvirus. Virology 178:161-165. 1990.

ATREYA, P.L., ATREYA, C.D. \& PIRONE, T.P. Amino acid substitutions in the coat protein result in loss of insect transmissibility of a plant virus. Proceedings of the National Academy of Sciences, U.S.A. 88:7887-7891. 1991.

ATREYA, P.L., LOPEZ-MOYA, J.J., CHU, M., ATREYA, C.D. \& PIRONE, T.P. Mutational analysis of the coat protein N-terminal amino acids involved in potyviral transmission by aphids. Journal of General Virology 76:265-270. 1995.

BRUNT, A.A., CRABTREE, K., DALLWITZ, M.J., GIBBS, A.J., WATSON, L. \& ZURCHER, E.J. (Eds.) (1996 onwards) Plant Viruses Online: Descriptions and Lists from the VIDE database. http: biology.anu.edu.au/Groups/MES/vide

CHRISTIE, S.R., EDWARDSON, J.R. \& ZETTLER, F.W. Characterization and electron microscopy of a virus isoled from Bidens and Lepidium. Plant Disease Reporter 52:763-768. 1968.

COSTA, A.S. \& KITAJIMA, W.E. Vírus do mosaico do picão ataca o girassol. O Estado de São Paulo, São Paulo. Suplemento Agrícola. 1966.

DELLA VECCHIA, M.G.S. Comparação de estirpes fracas e severas do Papaya ringspot virus com base na capa protéica. (Dissertação de Mestrado). Piracicaba. ESALQ/USP. 2001.

DOUGHERTY, W.G., ALLISON, R.F., PARKS, T.D., JOHNSTON, R.E., FEILD, M.J. \& ARMSTRONG, F.B. Nucleotide sequence of the 3' terminus of pepper mottle virus genomic RNA: evidence for an alternative mode of potyvirus capsid protein gene organization. Virology 146:282-291. 1985.

DUJOVNY, G., SASAYA, T., KOGANESAWA, H., USUGI, T., SHOHARA, K. \& LENARDON, S.L. Molecular characterization of a new potyvirus infecting sunflower. Archives of Virology 145:22492258. 2000.

DUJOVNY, G., USUGI, T., SHOHARA, K. \& LENARDON, S.L. Characterization of a Potyvirus infecting sunflower in Argentina. Plant Disease 82:470-474. 1998.

GAL-ON, A., ANTIGNUS, Y., ROSNER, A. \& RACCAH, B. A Zucchini yellow mosaic virus coat protein gene mutation restores aphid transmissibility but has no effect on multiplication. Journal of General Virology 73:2183-2187. 1992.

GEMTCHÚJNICOV, I. D. Manual de Taxonomia Vegetal: Plantas de interesse econômico. São Paulo. Editora Agronômica Ceres. 1976.

HOLLINGS, M. \& BRUNT, A.A. Potyviruses. In: Durstk, E. (Ed.) Handbook of Plant Virus Infections: Comparative diagnosis.
Amsterdam. Elsevier. 1981. pp.731-799.

KITAJIMA, E.W. \& LIMA, I.M. Infecção natural de zínia pelo vírus do mosaico do picão. Fitopatologia Brasileira 16:26. 1991. (Resumo) KUHN, G.B., LIN, M.T. \& COSTA, C.L. Transmissão, círculo de hospedeiras e sintomatologia do vírus do mosaico do picão. Fitopatologia Brasileira 5:39-50. 1980.

LORENZI, H. \& SOUZA, H.M. Plantas ornamentais no Brasil: arbustivas, herbáceas e trepadeiras. 2ed. São Paulo. Instituto Plantarum de Estudos da Flora. 1999.

McKERN, N.M., EDSKES, H.K., WARD, C.W., STRIKE, P.M., BARNETT, O.W. \& SHUKLA, D.D. Coat protein of potyviruses: Amino acid sequence of peanut stripe virus. Archives of Virology 119:25-35. 1991.

NAGATA, T., INOUÉ, A.K., DUSI, A.N. \& KITAJIMA, E.W. Bidens mosaic potyvirus newly isolated from pea, its characteristics and serological relationship with other potyviruses. Fitopatologia Brasileira 20:473-478. 1995.

SHERPHERD, J.F., SECOR, G.A. \& PURCIFULL, D.E. Immunochemical cross reactivity between the dissociated capsid proteins of PVY group of plant viruses. Virology 58:464-475. 1974.

SHUKLA, D.D., FRENKEL, M.J. \& WARD, C.W. Structure and function of the potyvirus genome with special reference to the coat protein coding region. Canadian Journal of Plant Pathology 13:178191. 1991.

SHUKLA, D.D., INGLIS, A.S., McKERN, N.M. \& GOUGH, K.H. Coat protein of potyviruses. 2. Amino acid sequence of the coat protein of potato virus Y. Virology 152:118-125. 1986.

SHUKLA, D.D., STRIKE, P.M., TRACY, S.L., GOUGH, K.H. \& WARD, C.W. The $\mathrm{N}$ and $\mathrm{C}$ termini of the coat proteins of potyviruses are surface-located and the $\mathrm{N}$ terminus contains the major virusspecific epitopos. Journal of General Virology 69:1497-1508. 1988. SHUKLA, D.D., WARD, C.W. \& BRUNT, A.A. The Potyviridae. Wallingford. CAB International. 1994.

SWOFFORD, D. PAUP: Phylogenetic analysis using parcimony. Version 4.0b10. Smithsonian Institution, Washington, D.C., 1997.

TRACY, S.L., FRENKEL, M.J., GOUGH, K.H., HANNA, P.J. \& SHUKLA, D.D. Bean yellow mosaic, clover yellow vein, and pea mosaic are distinct potyviruses: evidence from coat protein gene sequences and molecular hybridization involving the $3^{\prime}$ non-coding regions. Archives of Virology 122:249-261. 1992.

UYEDA, I. Bean yellow mosaic virus subgroup; search for the group specific sequences in the 3 ' terminal region of the genome. In: Barnett, O.W. (Ed.), Potyvirus Taxonomy. Archives of Virology 5 (Supplement). New York. Springer. 1992. pp.377-385.

VAN DER VLUGT, R.A.A., LEUNISSEN, J. \& GOLDBACH, R. Taxonomic relationships between distinct potato virus $\mathrm{Y}$ isolates based on detailed comparisons of the viral coat proteins and $3^{\prime}$ nontranslated regions. Archives of Virology 131:361-375. 1993.

WARD, C.W., McKERN, N.M., FRENKEL, M.J. \& SHUKLA, D.D. Sequence data as the major criterion for potyvirus classification. In: Barnett, O.W. (Ed) Potyvirus Taxonomy. Archives of Virology 5 (Supplement). New York. Springer. 1992. pp.283-297.

WARD, C.W. \& SHUKLA, D.D. Taxonomy of potyviruses: current problems and some solutions. Intervirology 32:269-296. 1991. 